\section{Victims of Dating Violence are Reviewed From Peer Group Emotional Support}

\author{
Ina Sarah Sarlita Moy, Sutarto Wijono, Izak Lattu \\ Fakultas Psikologi, Program Studi Magister Sains \\ Psikologi, Program Pascasarjana, \\ Universitas Kristen Satya Wacana Salatiga \\ Email:inna_dj5@yahoo.com
}

Journal PSIKODIMENSIA

Volume 18, No. 2,

Juni - Desember 2019

ISSN cetak : 1411-6073

ISSN online : $2579-6321$

DOI 10.24167/psidim.v18i2.2124

\begin{abstract}
The purpose of this study focuses on handling victims of courtship violence (KDP) through peer group emotional support. The characteristics of the peer group lead to emotional attachments such as a sense of belonging, love, closeness, trust, and acceptance by the group, which is not obtained from parents. Through peer groups, subjects are more free to tell stories, feel comfortable, safe, get solutions, attention and affection, even though conflicts sometimes occur. This study used the Participatory Action Research (PAR) method with a qualitative approach, namely through interview techniques, FGDs, evaluation, sharing and verbal and non-verbal motivation and recreation. Participants are domiciled in the city of Salatiga consisting of four people, one subject and three peer group members, with the same characteristics of age and sex, having friends for 2 years, having experienced $K D P$, and knowing the violence experienced by the subject. The results showed that although some social media through WhatsApp group (sharing quotes motivation) each other and members of the peer group experienced KDP, the subjects felt that there was emotional support finding identity, feeling confident, feeling valuable and being accepted. The next recommendation that can be given to the subject therapy for self-recovery or reconciliation with him and his ex-girlfriends such as Cognitive Behavior Therapy (CBT) and relationship restoration.
\end{abstract}

Keyword : Dating Violence; Peer Group; Emotional Support

\section{PENDAHULUAN}

Di Indonesia kasus Kekerasan terhadap perempuan, setiap tahunnya yang menempati urutan pertama adalah Kekerasan Dalam Rumah Tangga (KDRT) dan Kekerasan Dalam Pacaran (KDP) menempati urutan kedua. Data kekerasan dalam pacaran yang dilansir oleh Komnas Perempuan Anti Kekerasan menunjukkan jumlah kekerasan seperti tabel 1 dibawah.

\section{Tabel 1. Jumlah KtP pertahun}

\begin{tabular}{cc}
\hline Tahun & Jumlah Kasus \\
\hline 2013 & $\mathbf{2 7 9 , 6 6 8}$ \\
2014 & 293,22 \\
2015 & $\mathbf{3 2 1 , 7 5 2}$ \\
2016 & $\mathbf{2 5 9 , 1 5}$ \\
\hline
\end{tabular}

(Catahu 2017 Komnas Perempuan)

\begin{tabular}{cccr}
\multicolumn{2}{c}{ Kekerasan } & dalam pacaran \\
merupakan & faktor pembiasan dari \\
kurangnya & kelekatan atau hubungan
\end{tabular}


emosional antara orangtua dan anak. Kelekatan yang terjadi adalah kecenderungan orangtua kurangnya perhatian, menunjukkan rasa kasih sayang, menghargai dan mendukung. Pernyataan tersebut dijelaskan oleh Kolenc (2011) dalam penelitiannya bahwa kekerasan dalam pacaran yang dialami disebabkan pengalaman kekerasan dalam keluarga. Ketika menjalani sebuah relasi dukungan emosional sangat penting untuk menjaga keseimbangan kelekatan menjadi hubungan yang harmonis. Dukungan emosional merupakan suatu ikatan psikologi mendasar dalam menjalin sebuah hubungan baik itu dari orangtua, pertemanan maupun pacaran. Hasil temuan Adamson, Bains, Pantea, Tyrhwitt, Tolomiczenko dan Mitchell (2012) menjelaskan bahwa dukungan emosional memiliki sikap empati, simpati, dan kasih sayang kepada orang lain. Dukungan emosional mengacu pada bentuk perwujudan rasa empati seperti sikap suka dan tidak suka sebagai penegasan terhadap suatu objek (Trepte \& Reinecke, 2014). Penelitian sebelumnya dilakukan oleh Hikmah (2012) menyatakan bahwa dengan adanya dukungan emosional yang tinggi individu merasakan kenyamanan dan aman.

Dampak dari kekerasan dalam pacaran pun bermacam-macam seperti pada penelitian yang dilakukan oleh Safitri dan Sama'I (2013) terhadap Mahasiswa FISIP Universitas Jember (usia 18-21 tahun dan 22-24 tahun) mengemukakan bahwa (1) dampak psikologis yaitu: korban mengalami depresi, stres ; (2) dampak fisik yaitu: lebam, lecet, patah tulang, dan memar; (3) dampak seksual yaitu: mengalami traumatik, cemas, takut dan sering mengalami disorganisasi; (4) dampak sosial yaitu: dalam sebuah hubungan lakilaki cenderung mengendalikan dan mengontrol pasangan baik dalam hal pergaulan, penampilan ataupun pekerjaan. Alih-alih dari dampak kekerasan yang alami perempuan semata-mata karena atas nama cinta sehingga membentuk mind set perempuan bahwa adanya tindakan over protective yang dilakukan pasangannya itu adalah hal wajar atau dibenarkan, dengan demikian membentuk mekanisme pertahanan diri yang membuat korban (perempuan) memilih untuk bertahan dalam hubungan tersebut (Talise, 2016).

Sebuah teori sistem ekologi yang dikemukakan oleh Bronfenbrenner (2009) menjadi salah satu alternatif yang dapat digunakan sebagai pendekatan sistem dalam meminimalisir terjadinya korban kekerasan dalam pacaran. Teori ekologi sistem Bronfenbrenner terdiri dari 5 lapisan yakni lapisan pertama mikrosistem, yang berhubungan langsung dengan kehidupan individu seperti keluarga, teman, sekolah dan lingkungan tetangga. Lapisan kedua adalah mesosistem, proses berlangsung antara mikrosistem secara langsung dan secara tidak langsung mempengaruhi perkembangan kehidupannya seperti lingkungan sekolah dan dirumah sebagai penilaiannya. Lapisan ketiga eksosistem, perpaduan dari mikrosistem dan mesosistem yang tidak secara langsung mempengaruhi kehidupannya akan tetapi apa yang menjadi bagian dari aktivitasnya. Lapisan keempat yakni makrosistem mencerminkan budaya, pola perilaku, kepercayaan, adat istiadat dalam lingkungan individu. Lapisan terakhir yang kelima adalah menyangkut sosiohistoris atau kejadian sepanjang kehidupannya mulai dari kelahiran sampai pada kematian.

Oleh sebab itu, salah satu pendekatan yang tepat digunakan adalah melalui pendekatan mikrosistem. Salah satunya adalah interaksi individu dalam 
sistem ini adalah teman-teman sebayanya atau peer group. Pendapat tersebut didukung oleh Santrock (2012) yang mengatakan bahwa teman sebaya adalah remaja yang memiliki umur yang sama atau maturasi yang sama. Pendapat yang serupa oleh Foshee dkk. (2008) mengatakan bahwa peran teman sebaya memberikan dampak yang besar pada kepercayaannya. Penelitian juga dilakukan oleh Pranata (2014) bahwa peer group menggantikan ikatan keluarga, juga merupakan sumber afeksi, simpati dan pengertian, saling berbagi pengalaman dan sebagai tempat remaja untuk mencapai otonomi dan independensi. Ungkapan Papalia, Olds dan Feldman (2008), peran teman sebaya juga merupakan sumber kasih sayang, pengertian, simpati, dan tuntutan moral, yang digunakan sebagai tempat untuk bereksperimen serta sebagai sarana pencapaian kemandirian dan atau otonomi dari orang tua. Peran teman sumber afeksi, simpati, sumber kasih sayang adalah bentuk dukungan emosional. Hasil kajian Santrock (2012) menunjukkan bahwa salah satu bentuk dukungan emosional peer group adalah mampu mengekspresikan diri menunjukkan identitas diri. Dengan demikian individu merasa diperhatikan, disayang, didukung, diberi rasa empati, iba, sehingga subyek menghargai dirinya sendiri, mempersiapkan diri dengan menghadapi realita hidup. Penelitian yang dilakukan oleh Santrock (2012) menyatakan bahwa tingkat kelekatan antar teman sebaya bertambah tahun semakin dekat dan signifikan. Pernyataan yang sama oleh Lund (2013) (dalam Takeda \& Yamanaka, 2017)) mengatakan bahwa dukungan dari orang yang di sekitarnya, teman sebaya yang mengalami hal yang serupa dapat mereintegrasikan dan sangat efisien bagi individu ke arah yang lebih baik.Melalui pola kelekatan yang terjadi antara teman sebaya sering memunculkan ikatan emosional dengan sendirinya. Dengan kata lain di antara mereka tidak ada pemisah dan merasa adanya ikatan batin, merasa memiliki dan merasa bertanggungjawab satu dengan yang lain. Dengan adanya peer group membentuk suatu opini dan pandangan yang mengubah pola berpikir individu kearah lebih baik dan dengan menghargai dirinya sendiri sebagai makluk yang berharga, sehingga dari proses pengalaman dari dirinya individu dapat menjadi contoh atau rule kepada orang lain di sekitarnya.

Seyogyanya dampak dari peran teman sebaya bagi sesama anggota mereka adalah dampak positif, yaitu mereka dapat menasihati, memberikan informasi, pengertian dan pengalaman yang positif. Akan tetapi pada umumnya lebih nampak terjadi adalah dampak negatif, dimana bagi mereka yang mengalami kekerasan, cenderung memberikan kontribusi yang buruk terhadap teman sebayanya dengan menganggap bahwa kekerasan dalam pacaran merupakan hal yang wajar (Budiarti, 2015). Pernyataan ini di dukung oleh penelitian yang dilakukan oleh Sjioen (2016) menyatakan bahwa pelaku kekerasan cenderung berasal dari peer group yang melakukan kekerasan satu dengan lain, atau tindak kekerasan dipelajari dari peer group atau budaya kekerasan dalam pergaulan. Tidak menutup kemungkinan ketika berada dalam suatu percakapan atau obrolan mereka pasti akan membahas soal hubungan asmara dengan pasangan mereka. Tak ayal juga dalam proses bertukar pikiran itu adanya masukan yang malah menjerumuskan teman mereka dalam hal-hal yang negatif, misalnya tetap melakukan kekerasan terhadap pasangannya (bagi yang pelaku) dan bisa juga mereka tetap bertahan dengan pasangan mereka karena hanya itu salah 
satu upaya dalam melanjutkan hubungan mereka ataukah daripada terancam jiwanya (bagi korban). Walaupun sering terjadi konformitas dalam peer group akan tetapi mereka adanya kelekatan yang emosional. Oleh karena itu dalam penelitian ini memperbaharui pernyataan walaupun setiap peer group yang anggotanya mendapatkan dan atau melakukan kekerasan dalam pacaran cenderung memperlakukan (konformitas) anggota lainnya yang sama, akan tetapi tidak demikian. Sebaliknya mereka (anggota peer group) yang mendapatkan dan atau melakukan kekerasan dalam pacaran cenderung memperlakukan temannya dengan baik dengan memberikan pemikiran yang positif karena dalam komunikasi anak perempuan cenderung terbuka terhadap teman sebayanya, daripada anak laki-laki (Ellis, Dumas, \& Wolfe, 2012).

Dari sini penulis ingin memberikan argumen bahwa tidak semua peer group atau teman sebaya yang anggotanya mengalami kekerasan dapat membawa dampak buruk bagi teman sebayanya. Oleh karena itu penelitian ini sangat penting karena tujuannya untuk menangani masalah KDP melalui dukungan emosional peer group adalah pendekatan yang tepat bagi para korban KDP. Oleh karena itu, diperlukan kajian yang lebih mendalam lagi mengenai implementasi dukungan emosional dengan pendekatan peer group terhadap penanganan kekerasan dalam pacaran, khususnya korban yang memutuskan untuk berpisah dengan pasangannya, supaya kehidupan yang akan datang lebih bermakna atau kepada tujuan hidup yang diinginkan. Lokasi penelitian masalah KDP pada daerah Jawa Tengah, yaitu kota Semarang dan/atau Salatiga.

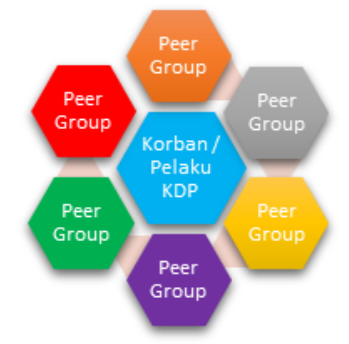

Gambar 2. Pola Penangganan KDP Terhadap Peer Group

\section{METODE}

Metode yang digunakan adalah metode PAR (Participatory, Action and Reaserch). Riset aksi menurut Creswell (2014) adalah proses untuk melakukan studi dan masalah secara ilmiah dengan tujuan mengarahkan, memperbaiki, dan mengevaluasi keputusan dalam pengambilan tindakan mereka dan melibatkan partisipan sebagai kolaboratif menuju perubahan.

Menggunakan teknik purposive sampling sampel yang diambil tidak berdasar pada populasi melainkan disesuaikan dengan tujuan penelitian, sehingga dapat dikatakan sebagai sampel bertujuan (Moleong, 2010). Untuk menjadi partisipan dalam penelitian ini penjaringan dilakukan di Kota Salatiga melalui komunitas-komunitas dan lingkungan kampus. Sasarannya adalah mahasiswa perempuan yang pernah mengalami kekerasan dalam pacaran khususnya telah berpisah dengan pasangannya.

Partisipasi pada penelitian ini berusia dewasa awal yang berumur 21 24 tahun yang berdomisili di Kota Salatiga, dimana subyek korban kekerasan dalam pacaran yang telah berpisah dengan pasangannya, sedangkan karakteristis partisipannya adalah orang terdekat dengan subyek, memiliki jenis kelamin yang sama, usia yang terpaut hampir 
sama, memiliki pengalaman hidup yang sama (korban dan atau pelaku), mengetahui kekerasan yang dialami subyek dan menjalin pertemanan kurang lebih 2 tahun bersama subyek.

Rancangan penelitiannya, dilakukan pendekatan wawancara, Focus Group Discussion (FGD), bedah kasus, dan lainlain. Dilakukannya aksi FGD maka di temukan subyek yang penah mengalami kekerasan dalam masa pacaran dan statusnya adalah telah berpisah dengan pasangannya. Perlakuan pemberian materi lebih mendalam dan terperinci mengenai tubuh, seks, seksualitas, relasi dan KDP. Kegiatan ini berlangsung selama 3 (tiga) hari dalam kelas Gender dan Feminisme. Agenda aksi adalah memberikan materi, diskusi, menemukan atau mencari pasangan kasus KDP sekitar lingkungan mereka tinggal, presentasi dan bedah kasus dalam kelas. Untuk menemukan pasangan kasus KDP ini mereka diberikan arahan dan pelatihan untuk mendampingan (identifikasi dan pemetaan analisis, solusi, refleksi, rekomendasi serta kode etik) atau langkah melakukan pendekatan terhadap kasus. Focus dalam penelitian adalah menangani perempuan korban kekerasan khususnya yang telah berpisah dengan pasangannya serta melibatkan peer groupnya. Kemudian penulis melakukan pendekatan secara persuasif dan intens, untuk melakukan wawancara. Teknik Wawancara dibagi menjadi 2 bagian data primer dan sekunder. Data primer yakni melakukan wawancara dengan subyek (korban) secara in-depth interview terhadap subyek. Menurut Bungin (2013) wawancara mendalam adalah tatap muka yang berulang-ulang antara subyek dan peneliti dan membutuhkan waktu yang lebih lama. Selanjutnya adalah pengambilan data sekunder yakni anggota peer group, dengan tujuan membandingkan sumber data sebelumnya. Wawancara terhadap subyek dan anggota peer group dilakukan secara terpisah dengan peer group sebanyak 3 kali pertemuan selama 2 bulan mengikuti karakteristik dari peer group adalah usia, budaya, jenis kelamin dan pengalaman yang serupa serta hubungan mereka lebih dari 2 (dua) tahun. Selain itu rekomendasi dari subyek yang menurut subyek, mereka merupakan teman dekat subyek yang mengetahui dan/ memahami kondisi subyek.

Rancangan penelitian dilakukan bersama peer group sebanyak 4 kali pertemuan, yakni pertemuan awal (pengenalan), pertemuan kedua sampai ke empat (evaluasi), dan diselingi dengan olah raga dan rekreasi bersama. Pertemuan awal, untuk mempertemukan subyek dan peer group secara bersamaan yaitu pengenalan. Aksi pengenalan ini penulis mengenalkan maksud dan tujuan pertemuan itu, setelah itu penulis meminta partisipan untuk mengisi formulir persetujuan sebagai partisipan dalam penelitian dan sebagai wujud komitmen bersama, mereka membuat bentuk surat pernyataan atau kontrak perjanjian serta menuliskan harapan dalam grup tentunya dengan tujuan mereka dapat saling memberikan kepercayaan, merekatkan persahabatan dan untuk menangani permasalahan yang dihadapi subyek. Langkah selanjutnya dalam pertemuan yang sama, penulis melakukan presentasi tujuan penelitian dan pemahaman atau informasi tentang arti teman dan fungsinya disertai dengan pemutaran video singkat. Setelah itu adanya brain storming atau mengemukakan ide yang kreatif dengan inisiatif atau kesadaran diantara mereka, yaitu menuliskan katakata motivasi atau quotes daily sebanyakbanyaknya dengan tujuan memotivasi atau membangkitkan semangat, harapan, pikiran yang positif dan meningkatkan self 
esteem yang difasilitasi media sosial WhatsApp (WA grup), kemudian quotes daily akan sharing setiap hari melalui media sosial. Pertemuan selanjutnya adalah melakukan evaluasi setiap minggunya sebagai evaluasi/sharing dan mengawal progress penanganan subyek dan peer group. Selain itu mengawal dan mendampingi subyek ketika subyek mengalami atau temui masalah selama dalam penelitian atau kontrak.

\section{HASIL DAN DISKUSI}

Keterlibatan partisipan merupakan langkah awal dari penguatan bagi subyek setelah berpisahnya dari pasangannya. Penentuan partisipan ini adalah awalnya subyek mengusulkan nama-nama partisipannya yakni subyek beranggapan bahwa mereka adalah orang-orang terdekat subyek dimana mereka memiliki jenis kelamin, usia yang sama, relasi yang cukup lama (lebih dari 2 tahun), dari budaya yang sama serta memiliki pengalaman yang serupa.

a. Usia, jenis kelamin dan relasi pertemanan

Irma (Subyek) : "dorang (mereka) ini sahabat beta (Saya), beta pung (saya punya) sahabat yang tahu beta pung masalah, cerita-cerita beta, kenal beta, teman kos, sering dengar beta pung curhat dan tahu kejadian kekerasan. Mereka juga adalah yang hampir setiap hari bertemu dengan beta atau jalan sama-sama dengan beta."

Eka (Partisipan 1) : "saya asal dari Sumba. saya kenal Irma itu dari tahun 2011, tidak terlalu kenal tapi tahu saja karena teman dari sepupu saya. Terus kami dekat ini itu sewaktu kami masih satu kos di akhir 2015 kemarin"

Yuna (Partisipan 2) : "saya asal dari Kupang. Saya kenal dengan Irma itu waktu kuliah di sini UKSW Salatiga, tahun 2016, ketemu Irma waktu itu pas kita mau wawancara waktu masuk kuliah."

Rena (Partisipan 3) : "saya berasal dari kota yang sama dengan Irma. Temanan baru 2011 waktu 2011 temenan untuk ngobrol, tapi untuk tahu Irma sudah dari tahun 2011",

\section{Analisis}

Adanya peran peer group dengan usia yang sama serta lamanya pertemanan merupakan hal yang terpenting. Karena memiliki karakter usia kronologis yang sama, adanya dukungan yang positif, merasa sepenanggungan, mengerti karakter perempuan membuat subyek semakin dikuatkan, di perhatikan.

Relasi pertemanan semakin lama, menggambarkan keterikatan secara psikologis yang lebih karena semakin merasa nyaman dalam berbagi cerita, keterlibatan semakin kuat ketika anggota subyek mengetahui permasalahan yang dialami oleh subyek.

\section{b. Pengalaman yang sama}

Eka (Partisipan 1) : "saya pernah alami kejadian sama kayak Irma, beta dulu pernah berpacaran sama mantan pacar saya, Dulu saya punya tipikal kayak Irma tapi tidak sampai yang seks begitu dan punya batasannya begitu, di tahun 2015 waktu saya masih kontrakan di Salatiga, tapi saya punya mantan di Yogya begitu. Jadi awalnya itu dia sudah punya anak mantan saya, jadi tidak direstui orangtuanya, jadi anaknya dibawa sama mantannya, mantan isterinya istilahnya begitu, jadi dia open minded dengan saya begini, begini, begini, tapi tidak tahu pas putus dengan satu, pas putus itu baru saya tahu dia tuh tipikal laki-laki PK (penjahat kelamin)" 
Rena (Partisipan 3) : "beta (saya) juga dulu adalah seorang pelaku tindak kekerasan terhadap beta punya cowok. Beta pernah pukul dia karena dia seng (tidak) ikut beta pung (punya) mau, beta usir dia, beta maki dia di beta pung kos, tapi itu dia seng omong apa-apa. Dia berpikir kalau beta pukul kembali dia maka katong (kita) putus su. Hahahha (ketawa bersama-sama). Beta waktu pukul dia dan maki dia beta rasa hebat, karena jarang ada perempuan pukul dia pung laki-laki haahaha (ketawa bersama-sama). Tapi beta seng (tidak) sampai lakukan hubungan seks deng dia.

\section{Analisis}

Dalam karakteristik ini menunjukkan bahwa masalah KDP ini bukan hanya di alami oleh subyek, tapi bagian dari anggota grup yang memiliki nasib yang sama atau cerita yang sama. Akan tetapi dibalik masalah yang ada mereka membuktikan bahwa mereka bisa keluar dan mengambil keputusan untuk berpisah dengan pasangannya, baik itu mereka yang menjadi korban maupun pelaku KDP.

\section{Dukungan Emosional Peer Group}

Pemberian dukungan emosional lewat media kata-kata motivasi, perhatian, iba, empati dan kasih sayang.

\section{Kata-kata Motivasi \\ Subyek}

Irma (Subyek) "beta (saya) dapat quotes daily ada yang menyakitkan kak, itu tulis beta pung (punya) nama langsung. Ini eka punya "icha harus berhati besar, harus menerima kenyataan." Ini orang mau move on hati tapuku (terpukul) kakak. Walaupun kata-katanya bagus, tapi menyakitkan sampai di hati harus menerima kenyataan. Maksudnya akang (artinya) bagus sih, tapi jujur saat baca itu beta menangis. Bahwa tidak sama kayak yang beta ekspetasi, yang beta harapkan. Kenyataannya beta masih punya rasa dengan dia to, walaupun dia pernah menyakiti beta pung perasaan ulang-ulang kali nih, beta punya perasaan ini."

"pagi ini saya mendapatkan salah satu quotes daily yang cukup menarik untuk direnungkan yaitu "kesalahan adalah bagian dari hidup. Mereka mengajarkan hal yang tak boleh kamu lakukan lagi. masalah adalah cara untuk membuatmu dewasa". Mendewasalah adalah hal menguatkan saya dan membuat saya terbayang akan pengalaman menyakitkan yang pernah saya lakukan bersama pasangan saya dulu”.

\section{Analisis}

Quotes daily ini diambil setiap hari secara acak oleh subyek maupun partisipan (anggota peer group) kemudian di share di grup dan pertemuan evaluasi. Quotes yang di dapatkan subyek Ini menunjukkan bahwa ketika adanya kata motivasi yang di dapatkan subyek bukanlah suatu kebetulan. Menyadarkan subyek bahwa perasaannya selama ini atau gejolak psikologis yang ada tidak bisa di pungkiri dan berat untuk dihilangkan begitu saja. Akan tetapi butuh perjuangan untuk melupakan secara perlahan-lahan dan menerima semuanya ini adalah suatu proses menuju kedewasaan.

\section{Empati dan Kasih Sayang}

\section{Peer Group}

Yuna (Partisipan 2) : "Yang sekarang dan yang penting sekarang itu adalah Irma harus kasih kembali dari 
sadarnya Irma, dibawah kontrolnya beta, memang beta yang bersedia, beta tau yang beta tahu, beta tau kalo beta sonde tau. Itu harus bikin ada dalam kuasanya beta sendiri............ Beta (saya) bisa, jangan bilang dulu beta, beta mau pisah tapi beta sonde (tidak) bisa. Kalo mau sadar itu harus "find something" harus temukan sesuatu kenapa harus membuat Irma mengerti dulu kenapa dan apa yang yang harus Irma hadapi"

\section{Analisis}

Percakapan ini merupakan awal dari pertemuan bersama peer group dan subyek, dimana subyek merasakan kebingungan setelah sekian lama terjadi kekerasan pada dirinya pada masa lampau. Pernyataan yang dilontarkan oleh partisipan 2 ini adalah upaya empati untuk membangkitkan semangat subyek untuk menyadari bahwa segala sesuatu yang terjadi harus di sadari, jangan di repress dalam alam bawah sadar dengan sengaja untuk menghilangkan rasa sakit atau kekerasan yang dialami. Subyek harus berupaya untuk sadar bahwa semuanya itu terjadi bukan untuk ditekan untuk dihilangkan akan tetapi harus mencari penyebab atau cikal bakal kekerasan ini dan menemukan jalan keluarnya.

\section{Perhatian dan Iba}

Eka (Partisipan 1) : "saya pernah alami kejadian sama kayak Irma, beta dulu pernah berpacaran sama mantan pacar saya, Dulu saya punya tipikal kayak Irma tapi tidak sampai yang seks begitu dan punya batasannya begitu, di tahun 2015 waktu saya masih kontrakan di Salatiga, tapi saya punya mantan di Yogya begitu. Jadi awalnya itu dia sudah punya anak mantan saya, jadi tidak direstui orangtuanya, jadi anaknya dibawa sama mantannya, mantan isterinya istilahnya begitu, jadi dia open minded dengan saya begini, begini, begini, tapi tidak tahu pas putus dengan satu, pas putus itu baru saya tahu dia tuh tipikal laki-laki PK (penjahat kelamin)"

\section{Analisis}

Partisipan (salah satu anggota peer group) yang ini sebelumnya merupakan korban kekerasan dalam pacaran. Pada kutipan percakapan diatas merupakan salah satu upaya perhatian Eka kepada subyek dengan bagaimana ia mencurahkan emosionalnya dengan katakata dan menyakinkan kepada subyek bahwa ia berupaya keluar dari permasalahan yang dihadapinya yang hampir sama dengan subyek. Upayaupaya ini terus Eka berbagi dengan subyek dengan harapan subyek dapat memahami dan mencoba untuk terbuka dan mencari jalan keluar. Karena baginya tidak mungkin jika ia melanjutkan hubungannya dengan mantan pacarnya dengan kondisi banyak faktor penghalang lainnya untuk dipertimbangkan.

Penelitian ini menunjukkan bahwa dukungan emosional peer group sangat melekat pada subyek, artinya subyek merasakan bahwa dukungan emosional seperti perhatian, empati, kasih sayang, iba yang diberikan teman sebayanya lebih besar dampaknya daripada sumber informasi dan sumber kognitif. Hal ini diperkuat dengan adanya perhatian peer group sehingga mereka merasakan apa yang subyek rasakan pada saat mendengar cerita dari subyek serta meresponnya dalam bentuk nasihat atau pengalaman psikologis mereka. Dilain waktu ketika subyek mengalami drop secara psikologisnya Irma mencoba untuk komunikasi dan anggota dari peer group memberikan pertolongan. Penelitian sebelumnya dilakukan oleh umumnya lebih nampak terjadi adalah dampak negatif, dimana bagi mereka yang sering 
atau mengalami kekerasan, cenderung memberikan kontribusi (konformitas) yang buruk terhadap teman sesamanya dengan menganggap bahwa kekerasan dalam pacaran merupakan hal yang wajar (Budiarti, 2015). Pernyataan ini di kuatkan dengan penelitian bahwa adanya perlakuan emosional negatif (verbal) karena desakan atau orang lain juga melakukan perilaku tersebut dengan spontanitas/nyata seperti memarahi subyek dan mengatakan subyek lemah, belum bisa move on, jangan bilang tidak bisa, tidak tahu, harus sadar dan mencari sesuatu untuk bangkit, dan lain-lainya, ketika subyek merasakan feeling blue. Selain daripada itu Sjioen (2016) menyatakan bahwa pelaku kekerasan cenderung berasal dari peer group yang melakukan kekerasan satu dengan lain, atau tindak kekerasan dipelajari dari peer group atau budaya kekerasan dalam pergaulan. Dengan kata lain bahwa mereka yang melakukan tindak kekerasan atau yang mengalami kekerasan dalam pacaran, tidak menutup kemungkinan dapat memberikan pengaruh yang besar terhadap teman atau kelompok dimana mereka bernaung. Akan tetapi dalam proses penelitian melalui evaluasi, sharing walaupun muncul konformitas antar mereka, ditemukan subyek merasa nyaman dengan anggota peer group. Perasaan ini muncul karena adanya pertama, perilaku anak perempuan lebih memiliki karakter sensitif, lembut, penuh kasih sayang dan empati (Lippa, 2012). Kedua, peer group menggantikan ikatan keluarga, juga merupakan sumber afeksi, simpati dan pengertian, saling berbagi pengalaman dan sebagai tempat remaja untuk mencapai otonomi dan independensi (Pranata, 2014). Juga, peran teman sebaya juga merupakan sumber kasih sayang, pengertian, simpati, dan tuntutan moral, yang digunakan sebagai tempat untuk bereksperimen serta sebagai sarana pencapaian kemandirian dan atau otonomi dari orang tua (Papalia, Old, dan Feldman, 2009). Ketiga, menyatakan bahwa dengan adanya dukungan emosional yang tinggi individu merasakan kenyamanan dan aman (Hikmah, 2012).

Oleh karena itu dapat disimpulkan fakta pembaharuan dalam penelitian ini adalah walaupun anggota peer group yang melakukan atau mengalami kekerasan memberikan kontribusi yang negatif kepada anggota lainnya dengan menganggap bahwa kekerasan yang dialami subyek adalah hal yang wajar, mereka dapat memberikan kontribusi positif selain mengenai informasi dan pengetahuan serta problem solving, subyek diberikan perhatian, kasih sayang, simpati dan empati serta pertolongan atau bantuan ketika subyek merasakan feeling blue dalam bentuk quotes daily dan verbal (kata-kata motivasi) melalui grup dalam media sosial WhatsApp. Media sosial WhatsApp dipakai oleh peneliti karena mengingat selain pertemuan tatap muka, teknik media sosial WhatsApp dapat menyentuh subyek melalui kata-kata motivasi yang dilakukan setiap hari antara mereka.

\section{SIMPULAN}

Kasus pada subyek bahwa peranan peer group menurut Santrock (2007) adalah peran peer group memberikan makna yang mendalam ketika melibatkan emosional, dimana subyek lebih terbuka, mendapatkan sentuhan, pelukan, perhatian, motivasi lewat kata-kata positif yang membangkitkan rasa menghargai diri, percaya diri, dipercaya, disayangi, dilindungi serta merasa berharga di hadapan teman-teman. Mereka percaya bahwa, perilaku anak perempuan lebih memiliki karakter sensitif, lembut, penuh kasih sayang dan empati (Lippa, 2012). 
Penelitian yang serupa yang menggambarkan dukungan positif peer group sangat penting yang dilakukan oleh Pranata (2014) yakni peer group merupakan suatu ikatan pengganti dari keluarga, tidak hanya itu saja, akan tetapi sebagai sumber afeksi, simpati dan pengertian, saling berbagi pengalaman dan sebagai tempat remaja untuk mencapai otonomi dan independensi. Ini membuktikan bahwa peranan peer group yang positif membentuk individu kearah kesadaran yang lebih baik, tinggi tanggungjawab, mandiri, memberikan pola pikiran yang positif akan kebermaknaan hidupnya atau hidupnya berharga, baik sebagai korban dan atau pelaku KDP.

Peranan peer group bukan sekedar berteman, tetapi kelekatan antara mereka menunjukkan bahwa adanya rasa saling percaya ketika mereka saling berkomunikasi melalui media sosial WhatsApp mereka dapat saling bertukar pikiran, sepenanggungan, dapat diandalkan serta menjaga kerahasiaan antara mereka. Selain itu konformitas kelompok mempengaruhi dan menentukan pilihan, membentuk pola pikir, memberikan penghargaan, meningkatkan percaya diri, bebas mengekspresikan kreatifitas dalam diri, ketulusan, keakraban, kehangatan, keterbukaan dan menghargai keberadaan mereka. Penelitian ini merupakan proses tahap penanganan terhadap subyek dan terdapat kekurangan oleh karena itu diperlukan adanya tindakan selanjutnya adalah tahap pemulihan dan reintergrasi seperti terapi kognitif perilaku atau Cognitive Behaviour Teraphy (CBT) dan Rekonsiliasi dengan Forgivness.

\section{DAFTAR PUSTAKA}

Adamson, K., Bains, J., Pantea, L., Tyrhwitt, J., Tolomiczenko, G., \& Mitchell, T. (2012). Understanding The Patient's Perspective of Emotional Support to Significantly Improve Overall Patient Satisfaction. Healthcare Quarterly (Toronto, Ont.), 15(4), 9-63.

Asmara. T. (2007). Efektifitas Bimbingan Kelompok dengan teknik Peer Group Dalam Meningkatkan Konsep Diri Siswa Kelas III A di SMP Mardisiswa 1 Semarang Tahun Pelajaran 2006/2007.Skripsi.Jurusan

Bimbingan dan Konseling Fakultas Ilmu Pendidikan Universitas Negeri Semarang.

Baron, R. A., Byrne, D. (2004). Psikologi Sosial. Jilid 1. Jakarta: Erlangga.

Bester, G. (2007). Personality Development of the Adolenscent : Peer Group versus Parents. South American Journal Of Education, 29(2). 25823984.

Budiarti, I. (2015) Hubungan Peran Teman Sebaya (peers) dengan Kejadian Kekerasan Dalam Pacaran di SMA N 1 Sanden Bantul. Skripsi. STIKes Aisyiyah. Yogyakarta. Publikasi.

Bungin, Burhan. (2013). Metodologi Penelitian Sosial dan Ekonomi. Jakarta: Prenemadia Grup. 
Cantos, A.L., Neidig, P.H., O’Leary, K.D. (1994) Injuries of women and men in a treatment program for domestic violence. Journal of Family Violence, 9(2), 113-124.

Collins, L.R, White, J.W. (2011). College Females ${ }^{\text {ee }}$ Decision to Stay or Leave an Abusive Relationship: A Test of the Investment Model. Thesis. The University of North Carolina at Greensboro.

Corey, S. (1953). Action Research to Improve School Practices. New York :Columbia University Teacher College Press.

Ellis, E. W., Dumas, C. J., Wolfe, A. D. (2012). Observations of Adolescent Peer Group Interactions as a Function of Within- and BetweenGroup Centrality Status. Journal of Research on Adolescence : Society for Research on Adolescence. 22(2), 252-266. DOI: $10.1111 / \mathrm{j} .1532-$ 7795.2011.00777.x

Ferlita, G. (2008). Sikap terhadap kekerasan dalam berpacaran: penelitian pada mahasiswi regular Universitas Esa Unggul yang memiliki pacar. Jurnal Psikologi, 6(1), 10-24.

Foshee, V.A., Karriker-Jaffe, K.J., Reyes, H.L.M., Ennett, S.T., Suchindran, C., Bauman, K.E., \& Benefield, T.S. (2008). What accounts for demographic differences in trajectories of adolescent dating violence? An examination of intrapersonal and contextual mediators. Journal of Adolescent Health, 42(6), 596-604.
Hamidi. (2005). Metode Penelitian Kualitatif. Malang: UMM Press.

Hikmah, N. (2012) Hubungan antara Dukungan Sosial Kawan Sebaya dengan Motivasi Berprestasi Alumni Siswa-Siswi SMAN 28 Jakarta Lulusan Tahun 2011.Skripsi. FISIP Program Sarjana Ilmu Kesejahteraan Sosial Depok.

Imani N, \& Pinasti S. V. I, Msi, (2014) Kissing Lips Sebagai Gaya Berpacaran Mahasiswa Modern di Yogyakarta. Skripsi. Universitas Negeri Yogyakarta

Janis, I.L., \& Mann, L. (1979). Decision Making: A Psychological Analysis of Conflict, Choice, and Commitment. London: The Free Press.

Kolenc, A. (2011). A Feasibility Study of an Adolenscent Dating Violance Intervention. Thesis. Kent State University Honor College.

Komnas Perempuan. (2012). Stagnansi Sistem Hukum: Menggantung Asa Perempuan Korban. Catatan KTP Tahun 2011. Jakarta: Komnas Perempuan.

Komnas Perempuan Komisi Nasional Anti Kekerasan terhadap Perempuan. Kekerasan dalam Pacaran. 21 Oktober 2017. Di akses pada https://www.komnasperempuan.go.i d/reads-kekerasan-dalampacaran\#sdfootnote1sym 
Komnas Perempuan. (2017). Labirin Kekerasan terhadap Perempuan: Dari Gang Rape hingga Femicide, Alarm bagi Negara untuk Bertindak Tepat, catatan KTP tahun 2016. Jakarta.

Lippa, R. A. (2010). Gender Differences in Personality and Interests: When, Where and Why. California: Blackwell Publishing.

LRC-KJHAM. (2016). Angka Kekerasan pada Perempuan di Jawa Tengah masih tinggi. Diakses dari https://www.hariankudus.com/2016 /11/28/angka-kekerasan-padaperempuan-di-jateng-masih-tinggi/. Harian Kudus.

Moleong, L. J. (2010). Metodologi Penelitian Kualitatif. Bandung: PT. Remaja Rosdakarya

Murray, J. (2007). Abusive Dating Relationships. United States. Harper Collins Publishers Inc.

Nisa, S. (2008). Konflik Pacaran Jarak Jauh Dewasa Muda. Skripsi. Fakultas Psikologi Universitas Gunadarma.

Papalia, D.E., Olds, S.W., \& Feldman, R.D (2008). Human Development (Psikologi Perkembangan Edisi Kesepuluh). Jakarta: Kencana

Perkumpulan Keluarga Berencana Indonesia. (2016). Nyari 1.000 Remaja DIY Hamil di Luar Nikah Tahun 2014. http://jogja.tribunnews.com/2016/0 1/24/nyaris-1000-remaja-diy-hamildi-luar-nikah-selama-2015. Tribun Jogja
Pranata. J. (2014). Hubungan Teman Sebaya Dengan Perilaku Berpacaran Mahasiswa Semester II D3 Keperawatan di Politeknik Kesehatan Majapahit. Skripsi. Publikasi. Mojokerto

Putri, N. R. P. N. (2016). Paradoks Cinta: Antara Pengorbanan dan Perpisahan (Kebertahanan Perempuan Korban Kekerasan dalam Perspektif Kelekatan Bowlby). Tesis. Program Studi Magister Psikologi. UKSW. Salatiga.

Poerwandari, E. K. (2007). Pendekatan Kualitatif untuk Penelitian Perilaku Manusia: Lembaga Pengembangan Sarana Pengukuran dan Pendidikan Psikologi. Fakultas Psikologi Universitas Indonesia Jakarta

Prabowo, Aan. (2013). Analisis Pemanfaatan Buku Elektronik (ebook) Berbasis Web oleh Pemustaka di Perpustakaan SMA Negeri 1 Semarang. Undergraduate Thesis, Ilmu Perpustakaan.

Rose, A. J., \& Rudolph, K. D. (2006). A Review Of Sex Differences In Peer Relationship Processes: Potential Tradeoffs For The Emotional And Behavioral Development Of Girls And Boys. Psychological Bulletin, 132, 98-131. doi:10.1037/00332909.132.1.98

Safitri, W. A \& Sama'i Drs. (2013). Dampak Kekerasan dalam Berpacaran. Skripsi. Fakultas Ilmu Sosial dan Politik. Publikasi. Universitas Jember. 
Santrock, J.W. (2012). Life-Span Development. Edisi Ketigabelas, Jilid Dua. (Alih bahasa: Mila Rachmawati dan Anna Kuswanti). Jakarta: Erlangga

Schurmn J. G. (Eds). (2009). The Ecology of Human Development; Experiments by Nature and Design Urie Brofenbrenner. Harvard Univeristy Press.

Trepte, S.D.T., \& Reinecke, L. (2014). Influence of Social Support Received in Online and Offline Contexts on Satisfaction with Social Support and Satisfaction with A Life : Longintudinal Study. Media Psychology, 18.

Vembriarto. (1993). Sosiologi Pendidikan. Jakarta: Gramedia.

Sjioen, Y (2016). Faktor-Faktor yang Mempengaruhi Tindak Kekerasan dalam Pacaran (Kajian Ekologi Bronfernbrenner pada Pelaku Kekerasan dalam Pacaran). Tesis, Universitas Kristen Satya Wacana, Salatiga.

States, J.E and Pirog-Good, M.A (1987). Violence in Dating Relationship. Social Psychological Quarterly, Vol. 50, No.3 (Sept., 1987). American Sociological Association. Accessed : 07-01-2019. https://www.jstor.org/stable/278682 $\underline{4}$

Susilowati, L. (2016). Antara Cinta dan Luka: Kajian Psikologi Transpersonal Terhadap Keputusan Berpisah pada Perempuan Korban Kekerasan Dalam Berpacaran. Tesis, Universitas Kristen Satya Wacana, Salatiga.

Takeda, J. \& Yamanaka, C.O.R. (2017). Participatory Action Research as an Approach to Empowerment of SelfHelp Group : Facilitating Social and Economic Reintegration of Women Migran Worker. Jurnal Penelitian. Mastery for Service : Social Sciences Review Vol.22. Kwansei Gakuin University. Japan 